第 36 回 奈良県医学検査学会 会長賞

\title{
術中神経モニタリングは術後神経合併症を予測できるか
}

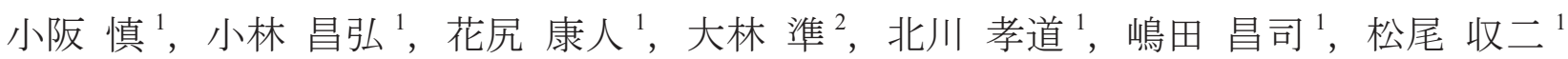

${ }^{1}$ 天理よろづ相談所病院 臨床検査部

2 天理よろづ相談所 医学研究所

当院で 2017 年 10 月からの 1 年間に実施された術中神経モニタリング 181 例を後ろ向きに調査し，術中神経モ ニタリングが術後神経合併症を予測できるか検討を行った．閉創時にアラームポイントを超える波形变化を認め たものを波形変化 $(+)$ ，術後に運動障害及び聴覚障害の出現したものを神経合併症 (+) とし，振幅 $50 \%$ 低下をカッ トオフ值とした場合，結果は感度 0.80 ，特異度 0.95 と良好であった．波形変化があるにも関わらず神経合併症を 認めなかった偽陽性の 9 例中 5 例はMEP と SEPが同時にモニタリングされ，うち4例がMEPのみ波形変化を認め， SEP は明らかな变化を認めなかった. MEP に変化を認める場合でも，SEPに変化を認めない場合は，神経学的 に予後は良好である場合が多く，MEP とSEPの multimodalityによるモニタリングが有用であった. また，偽陽 性の残り 4 例はSEP 単独でモニタリングされ，うち 3 例は SEP の振幅低下が $70 \%$ 以内であった. 術後神経合併 症の予防には振幅 50\%で注意喚起，70\%低下で警告といった段階的な警告の有用性が示唆された. 波形変化がな かったが神経合併症を認めた偽陰性の 1 例は頸椎後縦勒帯骨化症で，術直後は軽度の筋力低下であったが次第に 悪化を認め，C5 麻痺を生じたと考えられた．予測が難しい C5 麻痺については，今後さらなる検討が必要である．

キーワード：術中神経モニタリング，運動誘発電位（MEP），体性感覚誘発電位（SEP），聴性脳幹反応（ABR）

\section{Can intraoperative neurophysiologic monitoring predict postoperative neurologic complications?}

Shin Kosaka ${ }^{1}$, Masahiro Kobayashi ${ }^{1}$, Yasuhito Hanajiri ${ }^{1}$, Hitoshi Obayashi ${ }^{2}$, Takamichi Kitagawa ${ }^{1}$, Masashi Shimada ${ }^{1}$, Shuji Matsuo ${ }^{1}$

${ }^{1}$ Department of Laboratory Medicine, Tenri Hospital; ${ }^{2}$ Tenri Institute of Medical Research 
キースライド

1

対象

\begin{tabular}{|c|c|c|c|}
\hline \multicolumn{2}{|c|}{ 整形外科 127例 } & \multicolumn{2}{|c|}{ 脳神経外科 54例 } \\
\hline $\begin{array}{l}\text { 脊椎変性疾患 } \\
\text { (腰部冷柱管狭窄症、 } \\
\text { 难椎症性脊䯣症など) }\end{array}$ & 97例 & 脳腫瘍 & 23例 \\
\hline 圧迫骨折 & 8例 & 脳動脈瘤 & 22例 \\
\hline 側弯症 & 7例 & 内頸動脈狭窄症 & 5例 \\
\hline 頸椎後縦靭帯骨化症 & 6例 & 顔面痙攣 & 2例 \\
\hline 脊䯙腫瘍（䯙外） & 3例 & 脊髄腫瘍（髄内） & 1例 \\
\hline その他 & 6例 & その他 & 1例 \\
\hline
\end{tabular}

3 結果

\begin{tabular}{|c|c|c|c|c|}
\multicolumn{2}{c|}{} & \multicolumn{3}{|c|}{ 神経合併症 } \\
\cline { 3 - 5 } \multicolumn{2}{c|}{} & $(+)$ & $(-)$ & 合計 \\
\hline 波形変化 & $(+)$ & 4 & 9 & 13 \\
\hline 合計 & $(-)$ & 1 & 167 & 168 \\
\hline
\end{tabular}

感度 $80.0 \%$ 、特異度 $94.9 \%$

陽性的中率 30.8\%、陰性的中率 $99.4 \%$

5

偽陽性例

\begin{tabular}{|c|c|c|c|c|}
\hline & 診療科 & $\frac{\text { MEP }}{\text { 振湢低下 }}$ & $\frac{\mathbf{S}}{\text { 振融低下 }}$ & $\frac{\mathrm{EP}}{\text { 潜時延長(\%) }}$ \\
\hline (1) & 整形 & 72 & なし & なし \\
\hline (2) & 整形 & 70 & なし & なし \\
\hline (3) & 整形 & 実施せず & 69 & 8 \\
\hline (4) & 整形 & 実施せず & 67 & 4 \\
\hline (5) & 整形 & 実施せず & 50 & 13 \\
\hline (6) & 整形 & 実施せず & 73 & なし \\
\hline (7) & 脳外 & 50 & なし & なし \\
\hline (8) & 脳外 & 84 & なし & なし \\
\hline (9) & 脳外 & なし & 67 & なし \\
\hline
\end{tabular}

7 考察

•術後神経合併症を予測するうえで、 MEPとSEPの併用が有用である。

•症例によっては $50 \%$ 低下で注意喚起、 70\%低下で警告など段階的に警告を 行うことが有用である。
2

\section{方法}

\begin{tabular}{|c|c|c|c|}
\hline & $\begin{array}{l}\text { 運動誘発電位 } \\
\text { (MEP) }\end{array}$ & $\begin{array}{c}\text { 体性感覬誘発 } \\
\text { 電位(SEP) }\end{array}$ & $\begin{array}{c}\text { 聴性脳幹反応 } \\
\text { (ABR) }\end{array}$ \\
\hline 評価 & 運動機能 & 感覚機能 & 聴覚機能 \\
\hline 件数 & 65例 & 178例 & 2例 \\
\hline $\begin{array}{l}\text { アラーム } \\
\text { ポイント }\end{array}$ & 振幅50\%低下 & $\begin{array}{l}\text { 振幅 } 50 \% \text { 低下 } \\
\text { 潜時10\%延長 }\end{array}$ & $\begin{array}{c}\text { 潜時1.0ms延長 } \\
\text { ( V 波) }\end{array}$ \\
\hline
\end{tabular}

・手術終了時にアラームポイントを超える 変化を認めたものを波形変化（+）とした。 ・一過性の障害を除く運動障害及び聴覚障害 の出現したものを神経合併症（+）とした。

4

\section{真陽性例}

\begin{tabular}{|c|c|c|c|}
\hline & 疾患 & モニタリング & 術後合併症 \\
\hline (1) & 側弯症 & $\begin{array}{l}\text { MEP:波形消失 } \\
\text { SEP:潜時10\%延長 } \\
\text { 振幅5\%低下 }\end{array}$ & $\begin{array}{l}\text { 下肢筋力低下 } \\
\text { 下肢感覚障害 }\end{array}$ \\
\hline (2) & 脳腫瘍 & ABR:波形消失 & 恥覚障害 \\
\hline (3) & $\begin{array}{l}\text { 脳腫瘍 } \\
\text { (再手術) }\end{array}$ & $\begin{array}{l}\text { MEP:63\%低下 } \\
\text { SEP:術前より(-) }\end{array}$ & 片麻痺 \\
\hline (4) & $\begin{array}{l}\text { 脳腫瘍 } \\
\text { (再手術) }\end{array}$ & $\begin{array}{l}\text { MEP:91\%低下 } \\
\text { SEP:術前より(-) }\end{array}$ & 片麻痺 \\
\hline
\end{tabular}

6

\section{偽陰性例}

- 頸椎後縦勒帯骨化症

・MEP及びSEPは手術終了時に波形変化なし

・術後、右肩が上がらない（C5麻痺）

※C5麻痺について

- 頸椎手術に伴う合併症で三角筋と上腕二頭筋

の筋力低下をきたし、発生率は約5\%程度。

・術後に発症し、予測が難しい場合がある。

8

結語

・術中神経モ二タリングは術後神経合併症 をほぼ予測することが可能であった。

・予測が難しい遅発性C5麻痺については、 さらなる検討が必要である。 